\title{
PERMASALAHAN PENCEMARAN SUNGAI AKIBAT AKTIVITAS RUMAH TANGGA DAN DAMPAKNYA BAGI MASYARAKAT
}

\author{
Rabi Yati \\ Program Studi Pendidikan IPS Fakultas Keguruan dan Ilmu Pendidikan \\ Universitas Lambung Mangkurat \\ Banjarmasin \\ e-mail:2010128120009@mhs.ulm.ac.id
}

\begin{abstract}
Abstrak
Pencemaran air merupakan dimasukkannya atau masuknya macam benda, makhluk hidup, energi, zat dan komponen lain ke dalam air oleh kegiatan manusia, yang kemudian menyebabkan kualitas air menurun hingga ke tingkat tertentu sehingga air tidak dapat dimanfaatkan sesuai dengan kegunaan atau peruntukannya. Oleh karena itu, dengan mempertimbangkan fungsi sungai bagi masyarakat, ditulislah artikel ini yang bertujuan untuk mengkaji lebih dalam lagi mengenai fenomena tercemarnya air sungai akibat limbah yang dihasilkan dari aktivitas rumah tangga. Dengan menggunakan metode deskriptif kualitatif dan bertumpu kepada pengamatan fenomena di lingkungan sekitar sungai yang ada di Kalimantan Selatan serta hasil studi literatur dan referensi dari buku, penelitian dan artikel terdahulu, artikel ini mengangkat isu mengenai permasalahan lingkungan pencemaran air sungai yang disebabkan oleh aktivitas manusia terutama dari sektor rumah tangga. Sehingga dengan itu dapat diperoleh hasil dan ditarik kesimpulan bahwa sektor rumah tangga sangat rentan membawa pencemaran terhadap sungai, terutama pada masyarakat yang bermukim di bantaran atau di sepanjang sungai. Permasalahan-permasalahan pencemaran yang dibawa sektor rumah tangga antara lain, sampah organik atau anorganik yang dibuang begitu saja ke sungai, limbah hasil aktivitas rumah tangga seperti detergen yang digunakan untuk mencuci, dan lain-lain. Yang mana tentunya semua itu akan membawa pencemaran dan berdampak negatif terhadap sungai juga masyarakat, seperti menurunnya kualitas air sungai hingga membawa berbagai penyakit kepada manusia.
\end{abstract}

Kata Kunci: Sungai, Air, Rumah Tangga, Pencemaran

\section{Abstract}

Water pollution is the inclusion or entry of various kinds of objects, living things, energy, substances and other components into water by human activities, which then causes water quality to decrease to a certain level so that water cannot be utilized according to its use or designation. Therefore, taking into account the function of rivers for the community, this article was written which aims to examine more deeply the phenomenon of river water contamination due to waste generated from household activities. By using a qualitative descriptive method and relying on observations of phenomena in the environment around rivers in South Kalimantan as well as the results of literature studies and references from books, research and previous articles, this article raises the issue of environmental problems of river water pollution caused by human activities, especially from household sector. Thus, the results can be obtained 
and it can be concluded that the household sector is very vulnerable to bringing pollution to the river, especially for people who live on the banks of the tau along the river. Pollution problems brought by the household sector include organic or inorganic waste that is simply thrown into the river, waste resulting from household activities such as detergent used for washing, and others. Which of course will all bring pollution and have a negative impact on the river as well as the community, such as decreasing the quality of river water to bring various diseases to humans.

Keywords: River, Water, Household, Pollution

\section{Pendahuluan}

Sumber daya air merupakan hal yang sangat penting bagi manusia, dimana manusia dalam kehidupannya memerlukan air untuk bertahan hidup dan pada hakikatnya manusia tidak dapat hidup tanpa air, karena air diperlukan untuk minum, memasak, mencuci, mandi, dan aktivitas keseharian lainnya. Sumber daya air yang paling dekat dengan masyarakat salah satunya adalah sungai. Sungai di beberapa daerah termasuk Kalimantan Selatan dianggap memiliki peran yang sangat penting dan strategis di dalam kehidupan sehari-hari masyarakatnya. Hal ini juga di dukung dengan Kalimantan Selatan yang memiliki banyak sungai dan posisi Kota Banjarmasin sesungguhnya dikelilingi oleh sungai-sungai besar yang sangat vital fungsinya bagi pelayaran sehingga Banjarmasin selaku ibu kota Kalimantan Selatan disebut sebagai kota seribu sungai. Dengan beberapa sungai diantaranya yaitu Sungai Barito yang memiliki panjang mencapai $900 \mathrm{~km}$, Sungai Martapura dengan panjang $600 \mathrm{~km}$, Sungai Negara dengan panjang $85 \mathrm{~km}$, Sungai Tabalong dengan panjang $75 \mathrm{~km}$, dan diikuti dengan banyak anak-anak sungai lainnya. (Subiyakto, 2005)

Dengan daerah yang di dominasi oleh sungai dan banyak anak sungai inilah, masyarakat Kalimantan Selatan sejak dulu kala sampai pada sekarang terbiasa melakukan aktivitas di sekitar bantaran sungai, mulai dari mendirikan rumah di sepanjang sungai, alat transportasi yang digunakan juga memanfaatkan sungai, serta aktivitas keseharian seperti mencuci, mandi, dan aktivitas lain itu sebagian besar dilakukan di sungai. Bahkan sungai menjadi sarana transportasi masyarakat dan dimanfaatkan untuk jalur pengangkutan hasil alam seperti kayu dan batu bara, selain itu sumber air baku utama PDAM Kalimantan Selatan sebagian besar berasal dari air sungai. Dan salah satu yang unik dari Kalimantan Selatan adalah mendirikan pasar 
Sungai Terapung yang mana sistem pasar ini adalah menggunakan sungai sebagai suatu media atau tempat dalam melakukan kegiatan jual-beli, kegiatan ini memberi manfaat bagi masyarakat dan bertujuan untuk membantu meningkatkan perekonomian masyarakat sekitar. (Abbas E. W., et.al, 2020)

Dengan melihat fungsi sungai bagi masyarakat ini, tentunya sungai saingat rentan untuk tercemar karena sebagian besar aktivitas yang dilakukan di sungai seperti aktivitas domestik atau rumah tangga dan juga aktivitas pertambangan yang menggunakan sungai subagai jalur pengangkutan bahan hasil tambang. Sesuai dengan penelitian Kementerian Lingkungan Hidup dan Kehutanan 2018 yang diadakan pada beberapa sungai di Kalimantan Selatan terutama Sungai Barito dan Sungai Martapura, hasil penelitian pada beberapa sungai menunjukkan bahwa status kualitas air sungai di Kalimantan Selatan termasuk pada golongan tercemar berat. Dan faktor utama yang menyebabkan permasalahan lingkungan sungai adalah limbah yang dihasilkan oleh rumah tangga, limbah industri, dan limbah pertanian. Dimana sering kali masyarakat yang tinggal di sepanjang sungai dan masyarakat yang memanfaatkan sungai kurang memperhatikan kebersihan lingkungan sungai dan malah mencemari sungai dengan limbah dan sampah-sampah yang dihasilkan oleh rumah tangga, pabrik industri ataupun dari sektor pertanian. (Herliwati, et.al, 2021)

Oleh karena itu, dengan mengangkat fenomena permasalahan lingkungan hidup tersebut, artikel ini akan mengangkat isu mengenai permasalahan lingkungan pencemaran air sungai yang disebabkan oleh aktivitas manusia terutama dari limbah rumah tangga, yang tentunya akan berdampak kembali kepada masyarakat dan akan mengakibatkan permasalahan-permasalahan yang lebih kompleks lagi, mulai dari penurunan kualitas air sungai hingga membawa kepada penurunan pemanfaatan sungai karena masalah pencemaran lingkungan sungai tersebut.

\section{Metode}

Metode yang digunakan dalam artikel ini adalah metode deskriptif kualitatif. Metode kualitatif ini pada dasarnya merupakan suatu metode yang berdasar dari pengamatan kelompok atau individu baik itu dalam hal perilakunya maupun aktivitasnya secara mendalam. Metode kualitatif ini lebih mengutamakan hasil dan penarikan 
kesimpulan dari beberapa fakta sesungguhnya yang ada di lapangan (Jumriani, 2020).

Selain itu, artikel ini penyajiannya menggunakan metode deskriptif yang akan mendeskrepsikan dan menggambarkan secara rinci dan ringakas mengenai permasalahan lingkungan pencemaran sungai oleh limbah rumah tangga yang perhatian utamanya ditujukan kepada sungai-sungai Kalimantan Selatan. Adapun sungai-sungai sebagai objek yang dimuat dalam artikel ini adalah dari beberapa penelitian terdahulu di Sungai Barito, Sungai Martapura dan beberapa anak sungai yang bertempatkan di Banjarmasin dan Barito Kuala dan melakukan pengamatan terhadap perilaku masyarakat terutama interaksi rumah tangga dengan sungai yang mengakibatkan tercemarnya air sungai karena limbah yang dihasilkan oleh aktivitas rumah tangga yang dilakukan oleh warga sekitaran sungai yang bermukim di sana. Hal ini juga berhubungan dengan budaya masyarakat Kalimantan Selatan yang mendirikan tempat tinggal di atas sungai (rumah lanting).

\section{Pembahasan}

Pencemaran air merupakan dimasukkannya atau masuknya macam benda, makhluk hidup, energi, zat dan komponen lain ke dalam air oleh kegiatan manusia, sehingga menyebabkan kualitas air menurun hingga ke tingkat tertentu sehingga air tidak dapat dimanfaatkan sesuai dengan kegunaan atau peruntukkannya (UU No 23 Tahun 1997 tentang Pengelolaan Lingkungan Hidup). Pencemaran air ini dapat disebabkan karena suatu kesengajaan maupun ketidaksengajaan, yang mana faktor penyebab utama terjadinya pencemaran air yang paling mendominasi adalah akibat dari perbuatan atau aktivitas manusia. Dimana manusia-manusia yang tidak bertanggung jawab dan tidak memperdulikan tentang kebersihan lingkungan sungai cenderung melakukan aktivitas yang merusak lingkungan seperti membuang sampah, limbah zat kimia, limbah pabrik industri dan hal yang mencemari lainnya ke sungai.

Dalam Warlina, L. (2004) dijelaskan bahwa tanda atau indikator yang mencirikan bahwa air dalam suatu lingkungan telah tercemar antara lain adanya tanda-tanda atau perubahan yang dapat diamati, dan indikator tersebut dapat digolongkan menjadi 3 yakni Pengamatan secara fisik, kimiawi dan biologis. 
- Pengamatan secara fisik, adalah pengamatan pencemaran air berdasarkan tingkat perubahan warna, kekeruhan air (kejernihan), bau atau aroma yang dikeluarkan oleh air, perubahan suhu air dan rasa air.

- Pengamatan secara kimiawi, adalah pengamatan pencemaran air berdasarkan perubahan $\mathrm{pH}$ air dimana air normal dan memenuhi syarat memiliki $\mathrm{pH}$ antara 6,5 - 7,5 dan dilihat dari zat kimia yang terlarut dalam air.

- Pengamatan secara biologis, adalah pengamatan pencemaran air berdasarkan mikroorganisme yang terdapat dalam air sungai, terutama berdasarkan pemantauan adanya bakteri pathogen yang terkandung dalam air sungai.

Pencemaran terhadap air sungai menyebabkan penurunan kualitas air sungai, dimana yang biasanya air sungai dapat dimanfaatkan untuk hal-hal tertentu seperti untuk minum, mamasak, mencuci dan sebagainya, apabila air telah tercemar dan kualitasnya menurun air sungai tidak dapat lagi dimanfaatkan sebagaimana semestinya. Menurut Effendi (2003) dalam Sanjaya (2017) Kualitas air adalah karakteristik mutu air yang diperlukan dalam pemanfaatan tertentu dari sumber-sumber air. Secara sederhana air yang tercemar dapat diamati dengan mudah, misalnya dari tingkat kekeruhan air, karena pada umumnya orang awam berpendapat bahwa air bersih atau murni itu warnanya jernih dan tidak keruh, atau warnanya yang tembus cahaya atau bening, air yang tercemar juga dapat diidentifikasi dari baunya yang menyengat hidung, atau menimbulkan masalah pada kulit seperti gatal-gatal dan ada juga yang dapat merasakan dengan lidah, seperti rasa getir dan asam. (Arie Herlambang, 2006)

Adapun dari data tahun 2019 Dinas Lingkungan Hidup Kota Banjarmasin dapat dilihat bahwa hampir seluruh sungai di Banjarmasin menunjukkan baku mutu atau parameter status sungai telah melewati ambang batas kualitas air yang dianjurkan. Hal ini dapat dilihat dari konsentrasi atau kandungan COD dan BOD di sungai Martapura yang mencapai angka 19,2 mg/kg dan 34,2 mg/kg. Selain itu kandungan bakteri Escherichia coli di sungai Martapura mencapai 1600 MPN/ml dengan kandungan coliform tertinggi totalnya hingga $2400 \mathrm{mg} / \mathrm{l}$. Tingginya konsentrasi bakteri Escherichia coli di sungai Martapura ini tentunya diakibatkan karena banyaknya jumlah jamban 
yang didirikan diatas sungai oleh masyarakat yang tinggal di sepanjang sungai, sehingga menghasilkan limbah rumah tangga (domestik) yang menyebabkan pencemaran sungai. (Rismawati, L., et.al., 2020)

Dari pengamatan di berbagai sungai dan anak sungai di Kalimantan Selatan, dapat dilihat bahwa air di sebagian besar sungai terutama pada anak sungai Barito telah tercemar mulai dari sedang hingga kepada tercemar berat. hal ini dapat dilihat dari tingkat kekeruhan air sungai, aroma yang dikeluarkan, atau rasa air. Air sungai yang masih jernih, tidak berbau dan intensitas tercemar akan sampah rendah hanya terdapat pada air sungai yang jarang ada rumah warga atau hanya terdapat pada sungai yang sedikit penduduknya. (Warlina, L., 2004)

Oleh karena itu dapat disimpulkan bahwa faktor manusia, terutama faktor domestik atau rumah tangga yang merupakan faktor utama serta yang paling berpengaruh langsung terhadap pencemaran lingkungan sungai. Pencemaran terjadi karena faktor dari masyarakat sendiri yang tinggal di bantaran sungai tersebut, dimana persepsi ini bukan tanpa sebab, melainkan juga mempertimbangkan bagaimana berbagai aktivitas rumah tangga oleh masyarakat yang tinggal di sepanjang sungai yang menyebabkan tercemarnya air sungai serta kurangnya perhatian masyarakat terhadap kebersihan lingkungan. Kemudian hal ini lah yang menunjukkan bahwa faktor domestik atau faktor limbah rumah tangga lah yang menyebabkan tingginya tingkat pencemaran air sungai (Herliwati, et.al, 2021). Adapun penyebab yang mengakibatkan rumah tangga dianggap sebagai faktor utama yang paling berpangaruh terhadap pencemaran air sungai antara lain:

a) Sikap masyarakat yang cenderung acuh dengan kebersihan lingkungan dan tidak memikirkan dampak kedepannya sehingga mereka membuang sampah hasil rumah tangga ke sungai.

b) Kurangnya tempat penampungan sementara (TPS) di sekitar permukiman warga dan jarak permukiman warga ke tempat TPS yang relatif jauh sehingga masyarakat lebih memilih membuang sampah ke sungai. 
c) Kesalahan dalam mendirikan TPS, dimana masyarakat atau pihak berwenang mendirikannya di sisi sungai atau di tepi sungai sehingga sampah yang menumpuk akhirnya tetap akan meluber dan terbawa aliran sungai.

d) Budaya masyarakat Kalimantan Selatan yang mendirikan rumah diatas sungai (rumah lanting) yang menyebabkan seluruh aktivitas warga tidak terlepas dari sungai, hal inilah gang kemudian mengakibatkan pencemaran lingkungan baik sengaja ataupun tidak disengaja karena aktivitas kehidupan masyarakatnya yang tidak terlepas dari sungai.

e) Masih dipertahankannya jamban oleh masyarakat sebagai tempat BAK/BAB yang didirikan diatas sungai, dan biasanya hampir setiap rumah di pinggir sungai memiliki jamban.

f) Pemakaian sampah plastik yang berlebihan yang masih menjadi problematik di kalangan masyarakat karena dampak dari plastik terhadap lingkungan yang sangat merugikan, memiliki sifat yang sulit terurai diperkirakan membutuhkan waktu 100 hingga 500 tahun hingga dapat terurai (terdekomposisi).

g) Masyarakat yang tinggal di daerah sungai terbiasa beraktivitas seperti mencuci, mandi dan aktivitas lainnya di sungai, dimana detergen, shampo maupun sabun yang digunakan untuk mencuci atau mandi, zat kimia penyusunnya akan membawa dampak buruk terhadap kualitas air sungai dan biota yang ada di dalamnya.

Dilihat dari beberapa penyebab tersebut dapat diketahui bahwa masyarakat yang tinggal di sekitaran sungai lah yang membawa dampak utama terhadap pencemaran lingkungan air sungai, dimana limbah domestik atau limbah yang berasal dari rumah tangga ini dapat memberi dampak buruk terhadap lingkungan hidup yang kemudian akan membawa masalah yang lebih kompleks lagi kedepannya, baik itu untuk lingkungan hidup maupun bagi masyarakat itu sendiri. Sehingga masalah-masalah tersebut akan kembali ditanggung oleh masyarakat luas (Warlina, L. (2004). Adapun damapak yang dibawa oleh limbah rumah tangga antara lain: 
a) Menurunnya kualitas air sungai karena telah tercemar oleh sampah-sampah serta zat kimia yang dibawa dari limbah rumah tangga.

b) Hilangnya fungsi sungai yang semestinya bagi masyarakat, seperti aktivitas mencuci, mandi, maupun sebagai sumber air minum yang biasanya diambil dari air sungai menjadi tidak biasa dimanfaatkan lagi secara optimal karena sungai yang tercemar.

c) Membawa dampak penyakit yang menyerang saluran pencernaan, dan apabila air yang sudah tercemar bakteri Escherechia coli konsumsi dalam jangka panjang menyebabkan penyakit seperti diare, radang usus, infeksi saluran empedu dan saluran kemih. Karena tinja manusia dapat menghasilkan bakteri pathogen berupa Vibrio cholerae, Escherichia coli, Campylobacter jejuni, Shigella sp., dan Salmonella yang merupakan anggota dari fecal coliform (Prayitno, 2009; Deasy Arisanty, et.al, 2017).

d) Penggunaan deterjen saat mencuci disungai yang mengakibatkan eutrofikasi dimana hal tersebut mengakibatkan tingginya pertumbuhan ganggang maupun eceng gondok yang kemudian berdampak pada biota yang ada di sungai. Karena pertumbuhannya yang tinggi akan meningkatkan unsur hara, menghambat masuknya sinar matahari dan menghambat sirkulasi oksigen sehingga biota yang ada di dalam air kesulitan untuk bertahan hidup. Selain itu pencemaran air sungai akan bahan pembersih seperti deterjen, sampo dan jenis sabun lainnya yang berlebihan akan mengakibatkan zat kimia berbahaya yang menjadi penyusun detergen merusak kualitas sungai dan tanah sehingga air sungai tidak bisa dimanfaatkan sebagai air minum dan tanah kehilangan unsur haranya.

e) Sampah-sampah organik maupun anorganik yang merupakan limbah rumah tangga yang menumpuk disepanjang aliran sungai mengakibatkan bau yang menyengat sehingga mengganggu masyarakat yang tinggal di sekitaran sungai.

f) Sampah hasil limbah rumah tangga akan menyumbat aliran sungai sehingga apabila masuk musim penghujan atau intensitas air tinggi akan mengakibatkan sungai meluap sehingga banjir akan menggenangi daerah sekitar sungai, hal ini 
tentunya juga akan merugikan masyarakat baik secara materi maupun non materi.

Dari beberapa akibat diatas dapat diketahui bahwa pencemaran lingkungan sungai akan limbah rumah tangga sangatlah merugikan baik itu untuk lingkungan maupun bagi masyarakt itu sendiri. Maka daripada itu pemikiran jangka panjang untuk menjaga lingkungan sangatlah diperlukan bagi masyarakat yang tinggal di sekitar sungai agar sungai dapat dimanfaatkan seoptimal mungkin sesuai dengan fungsi sungai itu sendiri. Membuka kesadaran masyarakat terhadap keberhasilan lingkungan sungai adalah cara utama untuk mengurangi tingkat pencemaran air sungai, karena limbah yang dihasilkan masyarakat dari aktivitas rumah tangga lah yang menjadi faktor besar tercemarnya lingkungan hidup (Warlina, L., 2004). Adapun cara-cara yang dapat dilakukan untuk meminimalisir tercemarnya air sungai adalah:

a) Menumbuhkan kesadaran masyarakat akan peduli lingkungan hidup dengan mengadakan penyuluhan-penyuluhan ke berbagai wilayah sekitar sungai yang padat penduduk mengenai dampak-dampak negatif mengenai limbah rumah tangga bagi masyarakat dan lingkungan. Juga pembinaan kepada masyarakat dalam mengelola limbah rumah tangga agar lebih bermanfaat dan tentunya tidak mencemari air sungai.

b) Mengurangi pembuatan jamban yang didirikan langsung diatas sungai dan menggantinya dengan jenis jamban permanen atau semi permanen yang mana pembuangannya menggunakan saluran pembuangan yang saniter seperti menggunakan tangki septik.

c) Pembuatan TPS (Tempat Pembuangan Sementara) yang layak dalam hal letaknya yang strategis juga dalam hal manfaatnya yang optimal bagi masyarakat sekitar.

d) Mengurangi penggunaan kantong plastik dengan menggunakan tas serba guna apabila berbelanja, terutama di saat

e) Pembuatan instalasi pengelolaan air limbah dengan memanfaatkan teknologi modern yang akan mengelola limbah dan menghasilkan air bersih yang dapat 
menghilangkan senyawa kimia, bakteri serta substansi pencemar air lainnya, sehingga air dapat dimanfaatkan warga dengan baik.

f) Pembuatan kebijakan-kebijakan, larangan serta sanksi mengenai pembuangan sampah ke sungai oleh pihak yang berwenang agar memberikan efek jera kepada masyarakat yang masih membuang sampah ke sungai.

Dengan melihat beberapa cara dalam meminimalisir tingkat pencemaran air sungai diatas, dapat dikatakan bahwa dalam meminimalisir pencemaran air sungai diperlukan kerja sama dan tujuan yang terarah antara masyarakat dan pihak berwenang dalam menjaga lingkungan sekitar sungai, maka tingkat pencemaran air sungai dapat diminimalisir dan sungai dapat difungsikan sebagaimana semestinya secara optimal bagi masyarakat baik itu dalam kehidupan sehari-hari, sebagai mata pencaharian masyarakat sekitar maupun dikembangkan lagi sebagai tempat wisata. Untuk menciptakan lingkungan yang nyaman sangatlah diperlukan kesadaran masyarakat dalam menjaga lingkungan sekitar mereka agar lingkungan tersebut membawa manfaat yang baik bagi masyarakat. (Sanjaya, R. E., 2020)

\section{Simpulan}

Berdasarkan pengamatan sungai-sungai tertentu di wilayah Banjarmasin dan Barito Kuala dan bertumpu pada penelitian terdahulu, hasilnya menunjukkan bahwa kawasan sungai yang jarang penduduknya memiliki kualitas air yang lebih bersih dan baik dibandingkan dengan air sungai dengan kawasan padat penduduk. Dari pengamatan fenomena pencemaran air sungai tersebut serta juga didukung dengan penelitian terdahulu menunjukkan bahwa rumah tangga (domestik) menjadi faktor utama dan berperan besar yang telah memberikan dampak dalam pencemaran lingkungan sungai. Pencemaran terjadi karena faktor dari masyarakat sendiri yang tinggal di bantaran sungai tersebut, dimana persepsi ini bukan tanpa sebab, melainkan juga mempertimbangkan bagaimana berbagai aktivitas rumah tangga oleh masyarakat yang tinggal di sepanjang sungai yang menyebabkan tercemarnya air sungai serta kurangnya perhatian masyarakat terhadap kebersihan lingkungan. Hal ini

Pencemaran air ini juga tentunya akan membawa dampak negatif yang akan 
kembali kepada masyarakat itu sendiri, bahkan hal ini juga akan merembet ke masalah yang lebih kompleks lagi. Dimana apabila sungai tercemar yang merasakan akibatnya adalah masyarakat di sekitaran sungai itu sendiri. Masyarakat menjadi tidak dapat memanfaatkan sungai secara optimal karena kualitas air sungai yang menurun akibat pencemaran tersebut, sampai pada masalah ekosistem dan organisme yang hidup di dalam air sungai, hingga penyakit yang dibawa oleh bakteri seperti Escherichia coli yang menyerang kesehatan terutama saluran pencernaan manusia.

\section{Daftar Pustaka}

Abbas, E. W., Handy, M. R. N., Shaleh, R. M., \& Hadi, N. T. F. W. (2020). Ecotourism of Martapura River Banjarmasin as a Learning Resources on Social Studies. The Innovation of Social Studies Journal, 1(2), 111-119.

Ahya, R. R., Syaharuddin, S., \& Rahman, A. M. (2020). The Caring Attitudes for Environment of Lanting Householders as a Learning Resource on Social Studies. The Innovation of Social Studies Journal, 2(1), 66-74.

Arisanty, D., Adyatma, S., \& Huda, N. (2017). Analisis kandungan bakteri fecal coliform pada Sungai Kuin Kota Banjarmasin. Majalah Geografi Indonesia, 31(2), 51-60.

Handy, M. R. N., Mutiani, M., Putra, M. A. H., Syaharuddin, S., \& Putro, H. P. N. (2021). Adaptation of Riverbanks Community to Urban Green Open Space Development. The Innovation of Social Studies Journal, 2(2), 127-134.

Herliwati, H., Rahman, M., \& Rahman, A. (2021). ANALISIS INDEKS PENCEMARAN DAN DAYA TAMPUNG BEBAN PENCEMARAN SUNGAI JAING KABUPATEN TABALONG PROVINSI KALIMANTAN SELATAN. Fish Scientiae, 11(1), 70-82.

Machdar, I. (2018). Pengantar Pengendalian Pencemaran: Pencemaran Air, Pencemaran Udara, dan Kebisingan. Deepublish.

Mantaya, S., Rahman, M., \& Yasmi, Z. Y. (2016). Model Storet Dan Beban Pencemaran Untuk Analisis Kualitas Air Di Bantaran Sungai Batu Kambing, Sungai Mali-Mali Dan Sungai Riam Kiwa Kecamatan Aranio Kalimantan Selatan. Fish Scientiae, 6(1), 35-52.

Putro, H. P. N., \& Jumriani, J. (2020). KEHIDUPAN SOSIAL DAN EKONOMI MASYARAKAT BANTARAN SUNGAI A SEBAGAI SUMBER BELAJAR IPS.

Rismawati, L., Priatmadi, B. J., Hidayat, A. S., \& Indrayatie, E. R. (2020). Kajian Persepsi dan Perilaku Masyarakat Terhadap Pencemaran Air Sungai Martapura. EnviroScienteae, 16(3), 389-396. 
Sanjaya, R. E. (2020). Kualitas Air Sungai Di Desa Tanipah (Gambut Pantai), Kalimantan Selatan. KUALITAS AIR SUNGAI DI DESA TANIPAH (GAMBUT PANTAI), KALIMANTAN SELATAN.

Subiyakto, B., Abbas, E. W., Arisanty, D., Mutiani, M., \& Akmal, H. (2020). Sungai dan Kehidupan Masyarakat Banjar: Penguatan Lokalitas dalam Wacana Pendidikan IPS yang Responsif.

Susanto, B., Krisdianto, K., \& Satria, H. (2018). Kajian kualitas air sungai yang melewati Kecamatan Gambut dan Aluh Aluh Kalimantan Selatan. Bioscientiae, 6(1).

Warlina, L. (2004). Pencemaran air: sumber, dampak dan penanggulangannya. Unpublised). Institut Pertanian Bogor.

Yuniarti, Y., \& Biyatmoko, D. (2019). Analisis Kualitas Air Dengan Penentuan Status Mutu Air Sungai Jaing Kabupaten Tabalong. Jukung (Jurnal Teknik Lingkungan), 5(2). 